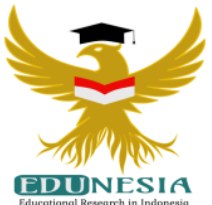

\title{
Peran Guru dalam Pelaksanaan Pembelajaran Jarak Jauh di Tengah Wabah Covid - 19
}

\author{
Siti Sabaniah"; Dadan F Ramdhan ${ }^{2}$; Siti Khozanatu Rohmah ${ }^{3}$ \\ 1,2,3 Pendidikan Guru Madrasah Ibtidaiyah, Universitas Sunan Gunung Djati, Indonesia \\ ${ }^{1}$ Corresponding Email: Sitisabaniah27@gmail.com , Phone Number : $0838 \times x \times x \times x \times x$
}

\begin{abstract}
Article History:
Received: Sept 09, 2020

Revised: Sept 24, 2020

Accepted: Sept 24, 2020

Published: Jan 01, 2021
\end{abstract}

\section{Keywords:}

Covid Outbreak 19,

Distance Learning,

Teacher Role.

\section{Kata Kunci:}

Peran Guru,

Pembelajaran Jarak

Jauh, Wabah Covid 19.

\section{How to cite:}

Sabaniah, S., Ramdhan, D.F., \& Rohmah, S.K. (2021). Peran Guru dalam Pelaksanaan Pembelajaran Jarak Jauh di Tengah Wabah Covid-19. Edunesia : Jurnal Ilmiah Pendidikan, 2 (1): $43-54$

This is an open access article under the CC-BY-NC-ND license
Abstract: Distance Learning should be well prepared from planning, implementing, to evaluating learning. This encourages research to examine how the role of teachers in the learning process is seen from the learning process. The focus of this research is to describe the Role of Teachers in the Implementation of Distance Learning, from the planning, implementation, and evaluation of learning. This research uses a descriptive qualitative research model. This research was conducted at MI Mathlau'ul Huda with the subject of the research being the teachers, in this case the teachers were given questionnaires and interviews to find out some indicators of the teacher's role, (1) the teacher's role as a source of learning in distance learning the teacher provided the source of learning among them namely the theme books and programs that the government made through television namely on TVRI; (2) the teacher's role as a demonstrator in this distance learning where the teacher provides facilities such as media for example with video media to help students in the learning process; (3) the teacher's role as a motivator gives the teacher motivating students. The motivation provided by the teacher also varies, there are those who provide motivation with rewards and also those that go directly to students (4) the role of the teacher as a manager in distance learning here the teacher acts as a manager of learning so that learning can be directed according to the basic competencies and learning objectives that must be achieved; (5) the teacher's role as an evaluator here the teacher's role is to provide an evaluation in order to know the extent to which students master a learning material.

Abstrak: Pembelajaran Jarak Jauh seyogianya harus dipersiapkan dengan baik dari mulai perencanaan, pelaksanaan, sampai kepada evaluasi pembelajaran. Hal ini mendorong penelitian untuk mengkaji bagaimana peran guru dalam proses pembelajaran yang dilakukan dilihat dari proses pembelajarannya. Fokus penelitian ini adalah untuk mendeskripsikan peran guru dalam pelaksanaan pembelajaran jarak jauh, dari mulai perencanaan, pelaksanaan, dan evaluasi pembelajaran. Penelitian ini menggunakan model penelitian deskriptif kualitatif. Penelitian ini dilakukan di MI Mathlau'ul Huda dengan subjek penelitiannya adalah para guru, dalam hal ini para guru diberikan angket dan wawancara untuk mengetahui beberapa indikator dari peran guru, (1) peran guru sebagai sumber belajar, dalam pembelajaran jarak jauh guru memberikan sumber belajar, yaitu buku tema dan program yang pemerintah buat melalui televisi yaitu di TVRI; (2) peran guru sebagai demonstrator, pada pembelajaran jarak jauh ini dimana guru memberikan fasilitas seperti, media contohnya dengan media video untuk membantu siswa dalam proses pembelajaran; (3) peran guru sebagai motivator, guru memberikan motivasi kepada peserta didik. Motivasi yang diberikan guru juga beragam ada yang memberikan motivasi dengan reward dan juga ada yang melalui langsung kepada peserta didik (4) peran guru sebagai pengelola, dalam pembelajaran jarak jauh disini guru berperan sebagai pengelola pembelajaran, agar pembelajaran dapat terarah sesuai dengan kompetensi dasar dan tujuan pembelajaran yang harus dicapai; (5) peran guru sebagai evaluator disini guru berperan untuk memberikan evaluasi agar mengetahui sejauh mana peserta didik menguasai suatu materi pembelajaran. Terakhir mengenai faktor pendukung dan penghambat peran guru dalam pelaksanan pembelajaran jarak jauh. 


\section{A. Pendahuluan}

Pandemi menimbulkan tantangan khusus bagi pendidik karena dalam situasi ini pembelajaran dilakukan secara online. Tentu saja, hal ini merupakan tantangan baru bagi pendidik, mulai dari metode pengajaran hingga individu di setiap mata pelajaran yang diajarkan oleh masing-masing guru. Pendidikan adalah hubungan antara guru dan siswa untuk mencapai tujuan pendidikan yang muncul di lingkungan pendidikan. Siswa akan menjadi faktor penentu sehingga dapat mempengaruhi segala yang dibutuhkan untuk mencapai tujuan pembelajaran (Wibowo, 2018). Pendidikan dapat diartikan dengan adanya suatu proses yang menggunakan metode untuk membuat mereka mengerti, pengetahuan dan bagaimana berperilaku saat dibutuhkan (Syah, 2014).

Menurut Undang-Undang Sisdiknas nomor 20 tahun 2003 Pendidikan adalah upaya sadar dan terencana untuk menciptakan suasana proses pendidikan dan pembelajaran, oleh karena itu, peserta didik secara aktif mengembangkan potensi mereka untuk memiliki kekuatan spiritual, kontrol diri, kepribadian, kecerdasan mulia dan keterampilan yang mereka butuhkan sendiri, bangsa dan masyarakat. Di negara ini, telah terjadi perubahan kurikulum yang memengaruhi perkembangan pendidikan. Dengan demikian, pendidikan adalah standar pengajaran di sekolah. Keberhasilan atau kegagalan dalam mengajar tergantung pada proses pengajaran yang dilakukan oleh guru. Mengajar adalah upaya sadar oleh seorang guru untuk membantu peserta didik sehingga mereka dapat belajar sesuai dengan kebutuhan dan minat mereka.

Mengajar adalah kegiatan yang dilakukan oleh seorang guru untuk memberikan pengetahuan kepada peserta didik. Belajar juga dapat didefinisikan sebagai interaksi belajar dan mengajar. Belajar terjadi sebagai proses interaksi antara guru dan peserta didik, dalam proses belajar, belajar dan mengajar saling terkait. Pendidikan dapat mencapai tujuannya jika pembelajaran masuk akal dengan pelatihan yang tepat. Di sisi lain, pendidikan tidak akan mencapai tujuannya jika pembelajaran tidak ada artinya dengan persiapan yang tidak memadai. Menurut Brunner's Learning Theory, ini adalah metode pembelajaran yang optimal dan deskriptif karena tujuan utama teori pembelajaran adalah untuk mendukung proses pembelajaran (Sulaiman, 2010).

Teori belajar memperhatikan hubungan antara variabel yang menentukan hasil belajar, atau bagaimana seseorang belajar. Sedangkan teori belajar memperhatikan bagaimana seseorang mempengaruhi pembelajaran orang lain, atau mencoba mengendalikan variabel-variabel dalam teori belajar untuk memfasilitasi pembelajaran. Mengajar pada dasarnya adalah upaya untuk menciptakan kondisi atau sistem lingkungan yang mendukung dan memungkinkan proses pembelajaran (Sardiman, 2012). Pembelajaran dapat diartikan secara luas sebagai tindakan guru untuk mengambil tindakan yang dapat mempengaruhi dan mengubah perilaku peserta didik. Dapat dikatakan bahwa pembelajaran berhasil jika pembelajaran dapat dilakukan sesuai dengan sistem kurikulum yang digunakan di lembaga pendidikan tempat proses pembelajaran berlangsung. Peran guru dalam proses pendidikan, khususnya, sebagai komunikator informasi dan penyelenggara (Wibowo, 2018). Definisi mengajar dan belajar secara umum, dalam proses mengajar sendiri peran guru tidak dapat dikecualikan. Karena dalam hal ini, belajar adalah interaksi antara guru yang menyebabkan perubahan perilaku. Di sekolah, guru adalah salah satu faktor utama dalam meningkatkan kualitas pengajaran. Karena itu, proses tersebut harus dirancang sedemikian rupa sehingga dapat memberikan hasil pembelajaran yang sesuai dengan yang diinginkan. Tidak mengherankan, berbagai filosofi 
dan metode pengajaran telah muncul di Indonesia yang terlihat baru dan modern, terlepas dari sumber pandangan mereka sebelumnya, bahkan jauh sebelum itu. (Juhji,2016).

Menurut Djamarah (2011) Guru dapat dipahami sebagai orang yang mengajar di tempat-tempat tertentu, memberikan pendidikan formal tambahan dan memberikan terapi reguler di masjid serta di rumah. Dari beberapa pandangan yang disajikan di atas, dapat dipahami bahwa guru adalah posisi yang terkait dengan orang tertentu, dan posisi ini wajib untuk mengajar dan belajar siswa yang terlibat dalam siswa.Beberapa ahli menguji serta meneliti mengenai teori-teori belajar, seperti teori pembelajaran konstruktif, teori pembelajaran terintegrasi, teori belajar aktif, teori pembelajaran kontekstual. Di sini guru membuat referensi yang baik dan percaya pada perubahan yang dapat meningkatkan kualitas peserta didik. Seorang guru adalah orang yang bertanggung jawab untuk mengajar di lembaga pendidikan tertentu. Dalam kosakata bahasa Indonesia yang besar, seorang guru dapat dipahami sebagai orang yang mengajar di sekolah, gedung, lokasi belajar, perguruan tinggi dan universitas. Pada proses pembelajaran yang dilakukan hari ini, metode pembelajaran pun tidak bisa berjalan sebagai mana mestinya, karena terkendala dengan adanya wabah covid-19, hal ini menjadi tantangan para guru untuk menentukan metode pembelajaran yang dapat di terapkan di masa pandemi.

Beberapa metode pembelajaran diterapkan selama pandemi, tetapi masih semua terbatas dalam hal institusi pendidikan dan guru sebagai staf pengajar. Karena wabah ini didefinisikan sebagai keadaan darurat kesehatan masyarakat yang mengkhawatirkan dunia dan penyebaran virus dengan sangat mudah, kita harus sadar bahwa virus ini ditularkan melalui kontak langsung dengan percikan pernapasan dari orang yang terinfeksi. Ketika wabah COVID-19 terus menyebar, orang harus mengambil tindakan untuk mencegah penularan lebih lanjut, mengurangi dampak wabah ini, dan mendukung upaya pengendalian penyakit. Perlindungan anak-anak dan lembaga pendidikan sangat penting. Kehati-hatian harus diambil untuk mencegah kemungkinan penyebaran COVID19 di sekolah, itulah sebabnya pemerintah menyerukan pendidikan di rumah.

Dengan demikian, kegiatan belajar mengajar terganggu oleh pembelajaran jarak jauh, inovasi dalam metode pembelajaran jarak jauh juga dirangsang oleh beberapa lembaga pendidikan. Berkenaan dengan lembaga pendidikan yang saat ini memiliki program pembelajaran jarak jauh, masyarakat umum sangat menyadari bahwa ini adalah salah satu lembaga pendidikan yang menyediakan pendidikan dengan sistem pembelajaran jarak jauh. (Sailah, 2011). Sistem pembelajaran jarak jauh (PJJ), dalam perkembangannya, sistem pembelajaran jarak jauh sangat diuntungkan dari perkembangan teknologi pengajaran, yang dapat diisi dengan kebutuhan akan pendidikan yang luas dan luas. Sementara Kearsey mengatakan bahwa pembelajaran jarak jauh adalah pembelajaran yang direncanakan di tempat lain atau di luar. Dengan demikian, pembelajaran jarak jauh memerlukan metode pengajaran khusus, metodologi khusus, komunikasi antara siswa dan guru (Yerusalem, 2015). Kemajuan pesat dalam teknologi telah mengarah pada penciptaan model pembelajaran jarak jauh yang fleksibel dan cerdas, serta akses terbuka ke pendidikan. Karena peran guru dalam proses belajar mengajar secara umum, peran guru tidak dapat dikecualikan, karena belajar adalah interaksi antara guru dan siswa (Wibowo, 2018).

Meskipun wabah COVID-19 secara signifikan mempengaruhi peran guru dalam berinteraksi dengan siswa, apakah keberadaan pembelajaran jarak jauh memungkinkan 
peran guru untuk berinteraksi dengan benar. Berdasarkan latar belakang masalah diatas dapat dirumuskan beberapa pertanyaan peneliti sebagai berikut:

1. Bagaimana proses pembelajaran jarak jauh di MI Mathla'ul Huda di tengah wabah COVID 19?

2. Bagaimana peran guru dalam pembelajaran jarak jauh di MI Mathla'ul Huda di tengah wabah COVID 19?

3. Apa faktor pendukung dan penghambat yang dihadapi oleh guru dalam pembelajaran jarak jauh di tengah wabah COVID 19 ?

\section{B. Metode}

Penelitian ini menggunakan pendekatan kualitatif yang dilakukan untuk menggali, memahami dan menggambar kan suatu objek penelitian. Dimana data kualitatif adalah pendekatan yang diperoleh dari wawancara, dokumentasi dan angket, metode yang digunakan dalam penelitian ini adalah metode desktirptif. Menurut Moleong, penelitian ini merupakan penelitian yang dapat menghasilkan data bersifat deskriptif berupa katakata berbentuk tulisan maupun lisan yang bersumber dari orang-orang dan perilaku yang diamati (Meleong, 2014). Menurut Arikunto (2013) menjelaskan bahwa penelitian studi kasus adalah penelitian yang dilakukan secara intensif, terinci, dan mendalam terhadap suatu organisasi, lembaga, atau gejala tertentu.

Dilihat dari wilayah penelitiannya, penelitian study kasus hanya meliputi daerah atau subjek yang sangat sempit, tetapi tinjauan dari sifat penelitian, penelitian studi kasus lebih mendalam. Penelitian ini akan dilaksanakan di Madrasah Ibtidaiyah Mathla'Ul Huda Baleendah Kabupaten Bandung Provinsi Jawa Barat Republik Indonesia. Waktu penelitian dilaksanakan pada Tahun Ajaran 2020/2021 yaitu pada Semester I bulan juni s.d selesai. Menurut Sutrisno pengamatan adalah proses yang bertautan, proses ini yang terdiri dari berbagai proses biologis dan psikologis (Sugiyono, 2013).Untuk menentukan sampling berikut, peneliti menggunakan teknik yaitu secara Non Probability Sampling (Purposive sampling) yang dimana sampel dipilih sesuai dengan yang dikendaki peneliti, sehingga sampel mewakili karakteristik yang diinginkan.alasan mengapa peneliti menggunakan Non Probability sampling karena hanya beberapa guru yang menjadi sampel di sekolah tersebut karena keterbatasan guru yang hadir ketika penelitian. Sejalan dengan teori menurut Arikunto (2010) purposive sampling yang digunakan oleh peneliti mempunyai pertimbangan-pertimbangan tertentu dalam mengambil sampelnya. Instrumen pengumpulan data yang digunakan yaitu angket/kuisioner dan wawancara.

Pemberian angket/kuisioner dan wawancara digunakan untuk mendapatkan hasil bagaimana peran guru dalam pelaksanaan pembelajaran jarak jauh pada mata pelajaran matematika yang telah disesuaikan dengan indikator peran guru. Pemberian angket/kuisioner dan wawancara dilaksanakan satu hari. Pertanyaan pada angket/kuisioner yaitu sejumlah 11 pernyataan dan untuk wawancara sejumlah 13 pertanyaan. Proses pengolahan data yang digunakan dalam penelitian ini diantaranya analisis untuk data hasil studi angket yaitu menggunakan statistik deskriptif. Analisis dilakukan untuk mengetahui presentase nilai peran guru dalam setiap hasil angket; dokumentasi dilakukan sebagai bentuk pengumpulan data dan sebagai penunjang untuk bukti telah dilaksanakannya penelitian; analisis terhadap data hasil wawancara dilakukan dengan tahapan sebagai berikut (a) membuat transkrip hasil wawancara; (b) mereduksi/memilah data dari transkrip hasil wawancara hingga mendapatkan 
keterangan dan/atau pendapat dari responden yang diperlukan dalam penelitian; (c) menyusun kesimpulan hasil wawancara.

\section{Hasil dan Pembahasan}

\section{Proses Pembelajaran Jarak Jauh Di MI Mathla'ul Huda}

Proses Penelitian ini dimaksudkan untuk mengetahui kondisi Pembelajaran, dari mulai perencanaan pembelajaran, media pembelajaran, sampai pada metode pembelajaran yang di gunakan dalam pelaksanaan pembelajaran jarak jauh. Hasil penelitian yang dilakukan dilihat dari beberapa isntrumen penelitian dari mulai angket, wawancara dan program penugasan yang guru buat sampai dengan evaluasi pembelajaran. Maka dapat dilihat Kondisi Pembelajaran di MI Mathla'ul Huda.

\section{a. Perencanaan Pembelajaran}

Dalam proses pembelajaran yang dilakukan guru dimasa pandemi dilakukan dengan cara pembelajaran jarak jauh, proses perencanaan yang sedari awal itu dilakukan secara langsung semua di ubah menjadi pembelajaran jarak jauh dikarenakan kebijakan pendidikan yang dikeluarkan oleh kementrian pendidikan dan kebudayaan melalui Surat Edaran Nomor 4 Tahun 2020 tentang Pelaksanaan Kebijakan dalam masa darurat Penyebaran Corona virus Disease (COVID-19) dimana surat edaran ini mempertimbangkan beberapa pelaksanaan yang harus dilakukan satuan pendidikan dalam pencegahan COVID-19 salah satunya yaitu dengan mengadakan pembelajaran secara daring.

\section{b. Media Pembelajaran}

Dalam pembelajaran, media adalah salah satu alat pendukung untuk berjalannya suatu proses pembelajaran. Dengan menggunakan media pada proses pembelajaran dapat mempermudah guru dalam memberikan pemahaman kepada peserta didik. Maka dari itu media merupakan hal penting dalam suatu proses pembelajaran. Menurut Miftah (2013) menyatakan berkenaan dengan perkembangan teknologi pembelajaran, peranan media menjadi sangat penting.

\section{c. Metode Pembelajaran}

Metode yang dapat dilakukan guru dalam pembelajaran jarak jauh dibagi menjadi dua kategori yaitu kelas 1,2, dan 3, kelas 4,5, dan 6. Bagi kategori kelas 1,2, dan 3 pembelajaran dilaksanakan dengan sistem aplikasi daring yang dibuat oleh guru dan di sampaikan kepada wali murid untuk membimbing siswa. Melalui metode ini materi disampaikan secara langsung oleh guru, aplikasi daring juga membuka ruang diskusi bagi peserta didik yang ingin bertanya di waktu yang sama. Untuk kategori kelas 4,5, dan 6 pembelajaran dilaksanakan dengan sistem diskusi terarah melalui aplikasi daring yang sudah dibuat oleh guru kelas.

\section{d. Evaluasi pembelajaran}

Proses evaluasi umumnya berpusat pada siswa. Ini berarti evaluasi dimaksudkan untuk menngamati hasil belajar siswa dan berupaya menentukan bagaimana kesempatan belajar. Dari pendapat di atas evaluasi dimaksudkan untuk mengamati suatu proses pengajaran, di dalamnya meliputi peranan guru, strategi pengajaran, materi kurikulum, dan prinsip-prinsip belajar yang diterapkan pada pengajaran. Itu sebabnya evaluasi menempati kedudukan penting dalam rancangan kurikulum dan rancangan pengajaran. 


\section{Peran Guru dalam Pembelajaran Jarak Jauh}

Saat ini, dunia sedang digemparkan dengan keadaan yang sangat memprihatinkan, dimana dunia sedang dilanda suatu wabah penyakit yang menyebar ke setiap penjuru dunia termasuk negara Indonesia. Wabah penyakit tersebut adalah wabah virus baru yang disebut dengan corovirus jenis baru (SARS-CoV-2) dan penyakitnya disebut Corona Virus Desease 2019 (COVID-19). Virus ini berasal dari Wuhan, China yang ditemukan pada akhir bulan Desember 2019. Karena hal tersebut, pembelajaran berubah dari yang biasanya pembelajaran dilaksanakan tatap muka menjadi pembelajaran jarak jauh yang tidak mengadakan kegiatan tatap muka antara siswa dan guru.

a. Peran Guru sebagai sumber belajar dalam Pembelajaran Jarak Jauh

Pada perencanaan pembelajaran jarak jauh ini guru-guru berperan sebagai sumber belajar dan pengelola dari prosesnya pembelajaran. Namun banyak perubahan dalam hal ini dengan adanya wabah covid-19, dengan adanya wabah yang terjadi maka pembelajaran menjadi pembelajaran jarak jauh.

Dengan ini kita bisa lihat juga dari hasil angket yang telah peneliti berikan kebeberapa guru di MI Mathla'Ul Huda sebagai b erikut:
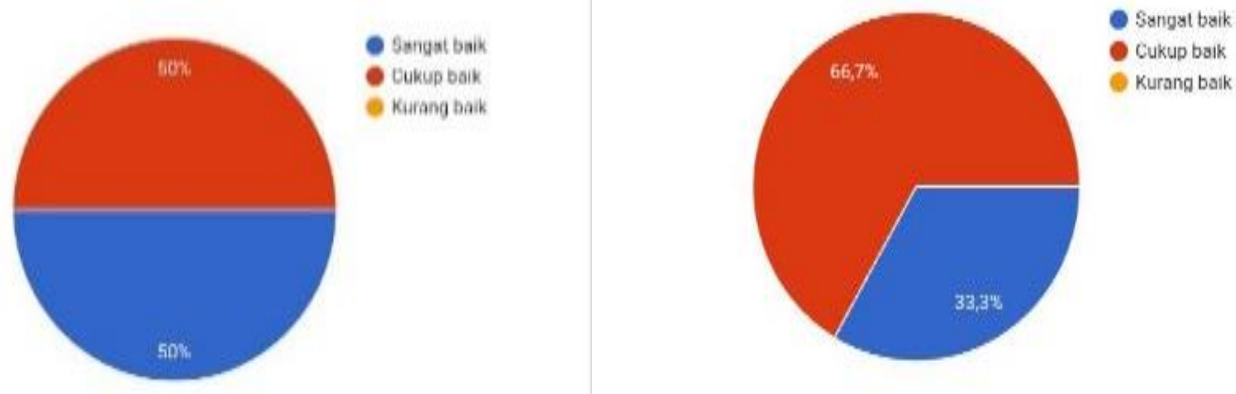

\section{Gambar 1. Hasil Persentase Soal Nomor 1 dan 2}

Dari gambar diagram lingkaran diatas, terdapat hasil jawaban dari soal nomor 1 yaitu mengenai peran guru sumber belajar dalam pembelajaran jarak jauh di tengah wabah covid-19. Ternyata dalam hal ini peran guru dalam perencanaan pembelajaran jarak jauh sebanyak 50\% menjawab bahwa masih bisa menguasai materi untuk di terapkan pada pembelajaran jarak jauh. Dalam hal ini, guru pun di tuntut untuk bisa merancang sebagaimana mesti nya untuk mengajar peserta didik walaupun dengan pembelajaran jarak jauh, walaupun $50 \%$ guru belum bisa merancang pembelajaran sedemikian.

\section{b. Peran Guru sebagai Demonstator dalam Pembelajaran Jarak Jauh}

Sesuai hasil wawancara dengan S2 mengenai implementasi media pembelajaran jarak jauh dengan menggunakan Grup Whats app, bahwa banyak keterbatasan dalam menggunakan media pada masa pandemi ini banyak keterbatasan dalam pemberian media. Pada proses pembelajaran, media pengajaran merupakan wadah dan penyalur pesan dari sumber pesan, dalam hal ini guru, kepada penerima pesan, dalam hal ini peserta didik. Dalam batasan yang lebih luas, memberikan batasan media pengajaran sebagai segala sesuatu yang dapat digunakan untuk merangsang pikiran, perasaan, perhatian, dan kemauan peserta didik sehingga mendorong terjadinya proses belajar pada 
diri peserta didik. Dengan hasil data wawancara diatas dapat di perkuat dengan hasil data anngket di bawah ini:
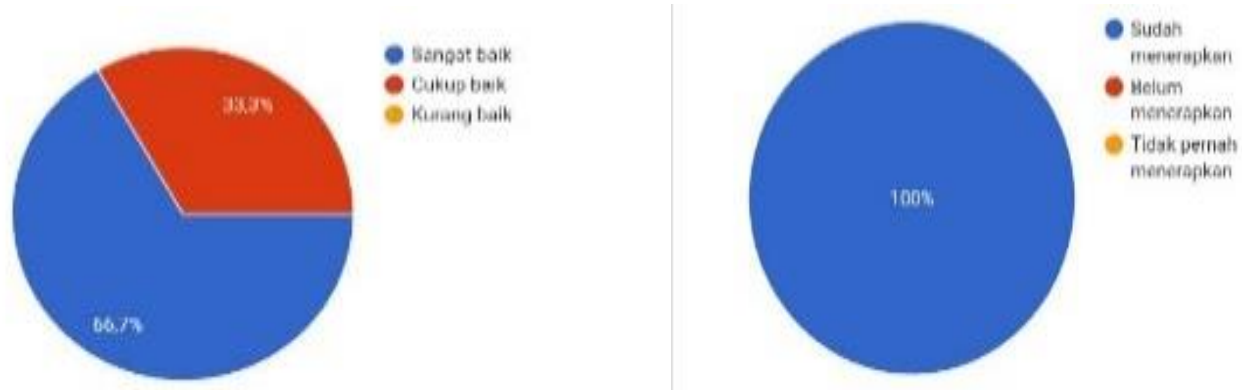

\section{Gambar 2. Hasil Presentase nomor 3 dan Nomor 4}

Berdasarkan hasil pada diagram presentase soal diatas, peran guru untuk peserta didik bisa memahami materi dalam pembelajaran jarak jauh, hasilnya 66,7\% "Sangat Baik", dengan keadaan wabah covid-19 guru tidak terlepas dengan peranan nya sebagai pendidik. Dalam ini guru merencanakan bagiamana peserta didik bisa lebih memahami sebagaimana guru telah menvapaikan materi dengan media WhatsApp, namun guru berusaha bagaimana peserta didik bisa mengerti pelajaran dengan pembelajaran jarak jauh. Berdasarkan hasil pada diagram persentase guru apakah sudah menerapkan strategi atau metode pembejaran dalam pembelajaran jarak jauh, hasilnya 100\% "Sudah Menerapkan". Peran guru sebagai demonstrator disini guru masih menggunakan strategi atau metode untuk menyapaikan pembelajaran jarak jauh walaupun dengan keadaan ditengah wabah Covid-19. Media pembelajaran merupakan alat bantu untuk guru dalam pelaksanaan pembelajaran. Dengan adanya media mempermudah guru dalam menyampaikan suatu materi kepada peserta didik agar lebih mudah memahami materi terutama pada mata pelajaran.

\section{c. Peran Guru Sebagai Motivator dalam Pembelajaran Jarak Jauh}

Pada proses pelaksanaan pembelajaran tentunya perlu untuk guru memberikan motivasi kepada peserta didik. Dengan adanya motivasi dari guru maka akan menumbuhkan rasa percaya diri pada diri peserta didik untuk terus berlatih dan berkembang menjadi lebih baik. Peran seorang guru sebagai motivator dalam proses motivasi belajar adalah salah satu aspek dinamis yang paling penting. Sering terjadi bahwa peserta didik dengan prestasi akademik yang buruk bukan disebabkan oleh kurangnya kemampuan, tetapi oleh kenyataan bahwa mereka tidak memiliki motivasi untuk belajar, sehingga ia tidak mencoba menggunakan semua kemampuannya. Karena itu, guru harus lebih kreatif dalam merangsang motivasi siswa. Diantaranya adalah penjelasan tentang tujuan yang ingin dicapai, membangkitkan minat peserta didik, menciptakan suasana belajar yang menyenangkan dalam belajar, pujian yang wajar untuk keberhasilan setiap siswa, mengevaluasi, mengomentari pekerjaan peserta didik dan menciptakan persaingan dan kerja sama antara peserta didik dan guru. 

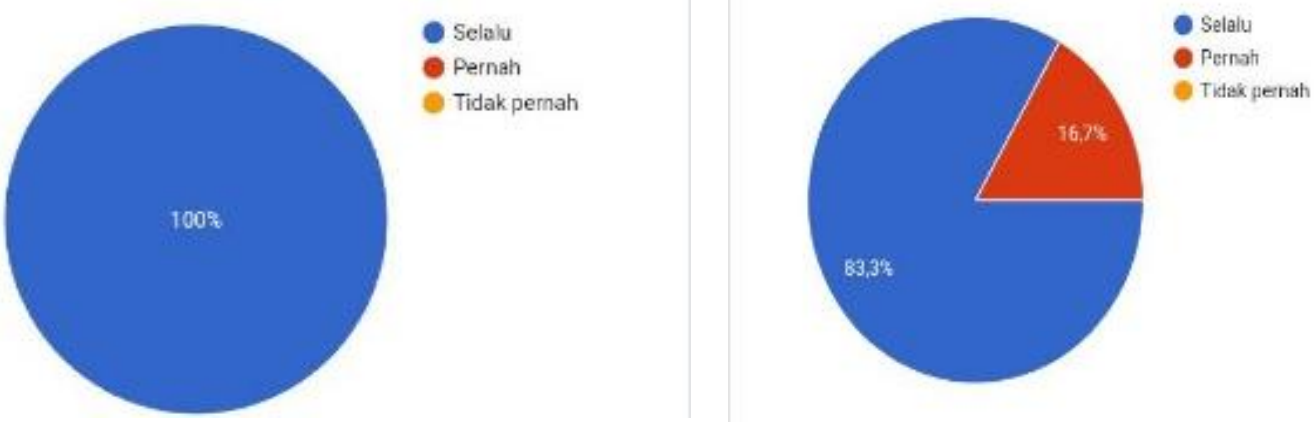

Gambar 3. Hasil Presentase Soal Nomor 5

Berdasarkan hasil pada diagram presentase soal mengenai apakah guru masih memotivasi peserta didik pada proses pembelajaran jarak jauh, hasilnya 100\% untuk guru memotivasi walaupun dalam pembelajaran jarak jauh. Sehingga dari hasil di atas menunjukkan bahwa peran guru sebagai motivator tetap dilaksanakan, karena dengan guru memberikan motivasi kepada siswa akan meningkatkan semangat peserta didik dalam belajar. Dalam hal ini motivasi penting untuk diberikan kepada peserta didik.

Sejalan dengan Sanjaya (2006) menyatakan Peran seorang guru sebagai motivator dalam proses motivasi belajar adalah salah satu aspek dinamis yang paling penting. Berdasarkan Hasil Pada diagram presentase soal guru selalu memotivasi secara langsung ( Via telepon/ video call) kepada peserta didik, hasilnya 88,3 \% " Selalu". Melihat dari hasil presentase soal Nomor 5 dan Nomor 6 disini peran guru dalam motivator peserta didik masih dilakukan oleh para guru, dengan ini guru masih memotivasi peserta didik dalam pembelajaran jarak jauh, sedangkan $16,7 \%$ guru masih memotivasi peserta didik walaupun secara tidak langsung. Namun para guru tidak terkepas dengan peranan guru sebagai motivator kepada peserta didik

\section{d. Peran Guru sebagai pengelola dalam Pembelajaran Jarak Jauh}

Pada proses pembelajaran jarak jauh ini, harusnya para guru membuat atau mempunyai metode alternatif dalam melakukan pembelajaran, karna metode adalah salah satu peran guru dalam pengelolaan pembelajaran ketika pembelajaran jarak jauh. Pada pembelajaran jarak jauh sendiri memang dalam perkembangan teori metode pembelajaran itu baru bisa di praktikkan pada masa perguruan tinggi / Universitas, sedangkan dalam proses penelitian ini dilakukan di Madrasah Ibtidaiyah (MI) berikut:

Adapun hasil angket yang telah peneliti berikan kebeberapa responden sebagai
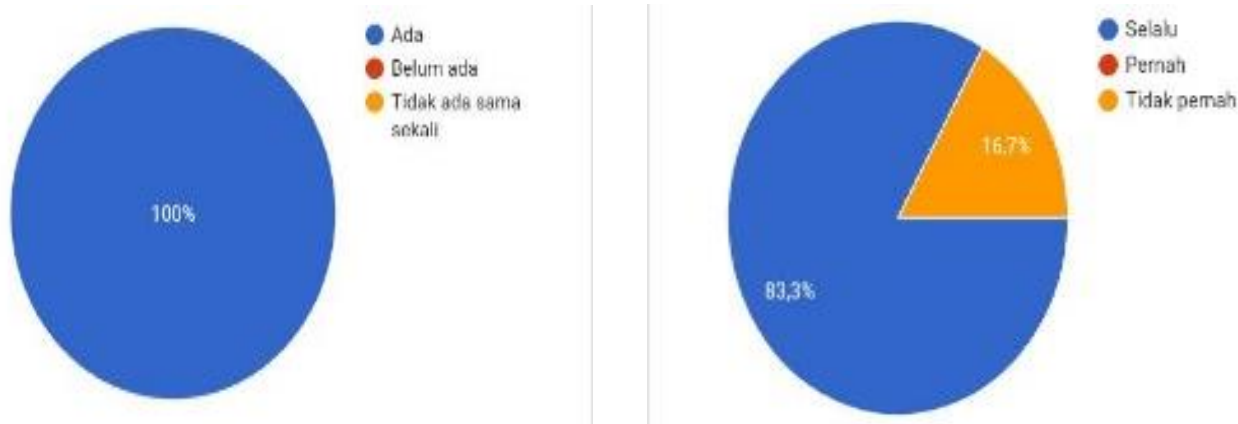

Gambar 4. Hasil Presentase Nomor 7 dan Nomor 8 
Berdasarkan hasil presentase diatas, peran guru dalam pengelolaan yaitu $100 \%$ "Ada" guru masih mengelola peserta didik pada pembelajaran jarak jauh. Namun pengelolaan dalam pembelajaran jauh tidak sama dengan pembelajaran pada mestiya. Banyak keterbatasan dalam mengeolala pembelajaran dengan metode yang seadanya. Tidak terlepas dengan telepon/ video call.

Berdasarkan hasil presentase diatas pengelolaan pembelajaran pada pembelajaran jarak jauh guru selalu mengelompokkan peserta didik, hasilnya 83,3\% guru masih menggunakan metode pengelompokan peserat didik. Akan tetapi 16,7\% guru masih belum memakai metode pengelompokan peserta didik dalam pembelajaran jarak jauh. Namun sebagain besar masih memkai metode pengelompokan peserta didik dengan Via Daring.

\section{e. Peran Guru dalam Evaluasi Pembelajaran Jarak Jauh}

Evaluasi merupakan bagian dari proses pembelajaran yang secara keseluruhan tidak dapat dipisahkan dari kegiatan mengajar, melaksanakan evaluasi yang dilakukan dalam kegiatan pendidikan mempunyai arti yang sangat utama, karena evaluasi merupakan alat ukur atau proses untuk mengetahui tingkat pencapaian keberhasilan yang telah dicapai peserta didik atas bahan ajar atau materi-materi yang telah disampaikan, sehingga dengan adanya evaluasi maka tujuan dari pembelajaran akan terlihat secara akurat dan meyakinkan. Para guru masih berperan untuk mengevaluasi pembelajaran jarak jauh
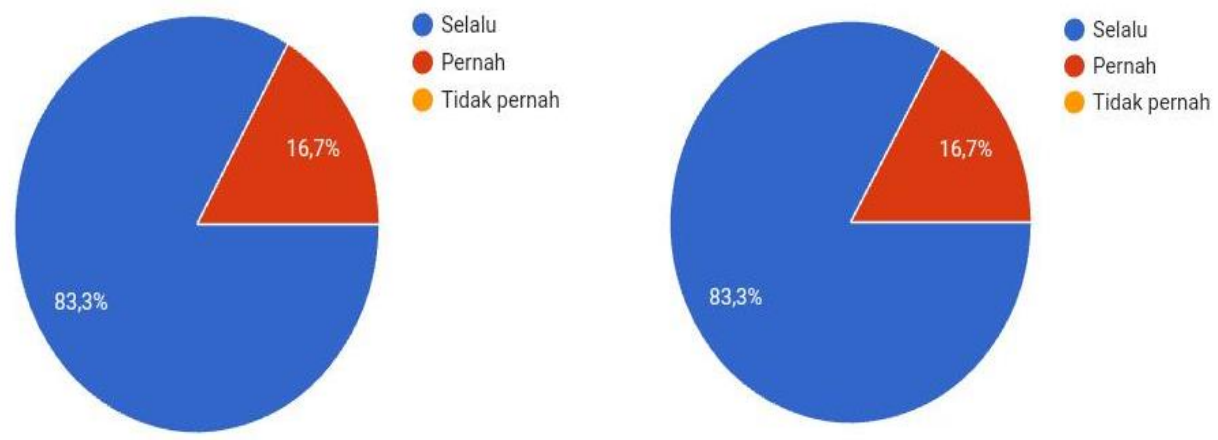

Gambar 5. Hasil presentase Nomor 9 dan Nomor 10

Berdasarkan hasil presentase guru selalu melaksanakan evaluasi dalam pembelajaran jarak jauh, hasilnya 83,3\% "Selalu" guru menggunakan evaluasi meski pembelajaran jarak jauh dengan beberapa pemberian nilai via daring. Namun $16,7 \%$ "pernah" evaluasi peserta didik secara berkala. Berdasarkan hasil presentase di atas, guru masih adakah hambatan mengevaluasi peserta didik saat pembelajaran jarak jauh, hasil nya 83,3\% "Pernah" terhambat dalam proses mengevaluasi peserta didik saat pembelajaran jarak jauh. Karena ketika evaluasi pembelajaran jarak jauh tidak sama dengan pembelajaran jarak jauh. Namun dalam proses pembelajaran jarak jauh para guru tidak bisa menggunakan evaluasi secara langsung yang biasa di gunakan dalam pembelajaran langsung, maka dalam hal ini para guru menyepakati untuk menggunakan evaluasi yang dapat menunjang proses pembelajaran jarak jauh / Daring, dalam hal ini para guru menggunakan Group WhatsApp. Untuk menyampai evaluasi pembelajaran. 


\section{Faktor Pendukung dan Penghambat dalam Pembelajaran Jarak Jauh}

Sehingga dapat di simpulkan faktor pendukung dalam pelaksanaan pembelajaran jarak jauh yaitu :

a) Faktor pendukung dari pemerintah yang membuat program pembelajaran melalui televisi.

b) Faktor pendukung dari sekolah yang memberikan dana internet setiap bulannya.

c) Faktor pendukung dari orang tua yang bekerja sama dalam membimbing peserta didik pada pelaksanaan pembelajaran jarak jauh

d) Faktor Penghambat dalam Pembelajaran Jarak Jauh

Sehingga dapat di simpulkan faktor penghambat dalam pelaksanaan pembelajaran jarak jauh yaitu :

a) Tidak semua siswa dan orangtua mampu memenuhi kebutuhan seperti kuota internet dan tidak semua orangtua memiliki handphone canggih.

b) Kurangnya pengetahuan orangtua tentang penggunaan aplikasi internet.

c) Pengumpulan tugas yang terlambat dikarenakan hanya memiliki satu handphone.

d) Guru kesulitan dalam menjelaskan materi apabila siswa merasa kesulitan.

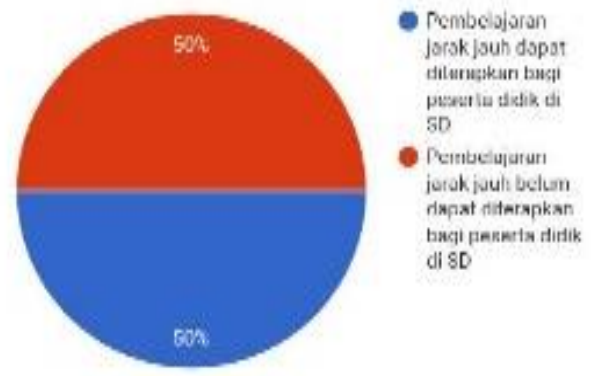

Gambar 6. Hasil Presentase Nomor 11

Berdasarkan hasil persentase diatas, pembelajaran jarak jauh $50 \%$ pembelajaran jarak jauh masih bisa diterapkan di Mi, namun 50\% guru berpendapat pembelajaran jarak jauh belum dapat di terapkan di MI. Pada Hasil Wawancara, Program Penugasan, dan Angket yang telah di berikan kepada responden (Guru), dari 10 guru kelas , 6 Guru dijadikan Sample dalam penelitian kali ini mengenai Peran Guru dalam Pembelajaran Jarak Jauh menghasilkan $94 \%$ menyatakan bahwa peranan guru sangat berpengaruh pada proses pembelajaran yang dilakukan.

\section{Kesimpulan}

Berdasarkan hasil penlitian dan pembahasan dapat ditarik kesimpulan sebagai berikut: Kondisi umum pembelajaran jarak jauh di MI Mathla'ul Huda terlaksana dengan baik dan sesuai dengan intruksi dari pemerintah yang mengharuskan pembelajaran dilakukan secara daring dalam situasi pandemi COVID-19 yang dimana pembelajaran tidak dapat dilaksanakan secara tatap muka di kelas.

Peranan guru dalam pembelajaran jarak jauh ini ada beberapa indikator yang peneliti ambil yaitu peran guru sebagai sumber belajar, demonstrator, motivator, pengelola, dan evaluator. Berdasarkan hasil wawancara menunjukkan bahwa penerapan 
kelima indikator tersebut terlaksana dengan baik. Pelaksanaan tersebut meliputi : (1) peran guru sebagai sumber belajar dalam pembelajaran jarak jauh ini guru memberikan beberapa sumber belajar diataranya yaitu pada buku tema dan program yang pemerintah buat melalui televisi yaitu di TVRI; (2) peran guru sebagai demonstrator pada pembelajaran jarak jauh ini guru membantu siswa dalam proses memahami suatu materi yang dimana guru memberikan fasilitas seperti media contohnya dengan media video untuk membantu siswa dalam proses pembelajaran; (3) peran guru sebagai motivator guru disini tetap memotivasi siswa walaupun pembelajaran dilakukan secara daring. Motivasi yang diberikan guru juga beragam ada yang memberikan motivasi dengan reward dan juga ada yang melalui langsung kepada siswa dan ada juga yang memotivasi siswa melalui kerja sama dengan orang tua. (4) peran guru sebagai pengelola dalam pembelajaran jarak jauh disini guru berperan sebagai pengelola pembelajaran agar pembelajaran dapat terarah sesuai dengan kompetensi dasar dan tujuan pembelajaran yang harus dicapai; (5) peran guru sebagai evaluator disini guru berperan untuk memberikan evaluasi agar mengetahui sejauh mana peserta didik menguasai suatu materi pembelajaran. Dalam pembelajaran jarak jauh ini ada beberapa faktor pendukung dan faktor penghambat. Faktor pendukung tersebut yaitu (1) faktor pendukung dari pemerintah yang membuat program pembelajaran melalui televisi; (2) faktor pendukung dari sekolah yang memberikan dana internet setiap bulannya; (3) Faktor pendukung dari orang tua yang bekerja sama dalam membimbing siswa pada pelaksanaan pembelajaran jarak jauh. Faktor penghambat tersebut yaitu (1) tidak semua siswa dan orang tua mampu memenuhi kebutuhan seperti kuota internet dan tidak semua orang tua memiliki handphone canggih; (2) kurangnya pengetahuan orangtua tentang penggunaan aplikasi internet; (3) pengumpulan tugas yang terlambat dikarenakan hanya memiliki satu handphone; (4) guru kesulitan dalam menjelaskan materi apabila siswa merasa kesulitan.

\section{Daftar Pustaka}

Arikunto, S. (2013). Penelitian tindakan Kelas. Jakarta: Bumi Aksara.

Djamarah, S. B. (2011). Guru Dan Anak Didik Dalam Interaksi Edukatif. Jakarta: Rieneka Cipta.

Juhji. (2016). Peran Guru dalam Pendidikan . Jurnal Ilmiah Pendidikan , 14-18.

Meleong, 1. J. (2014). Metodologi Penelitian Kualitatif. Bandung: Remaja Rosdakarya.

Sailah, I. (2011). Penyelenggaraan Model Pembelajaran Pendidikan Jarak Jauh di perguruan tinggi . Kementrian pendidikan Nasional, hal.4.

Sardiman, A. (2012). Interaksi Dan Motivasi Belajar Mengajar . Jakarta : Raja Grapindo Persada.

Sugiyono. (2013). Metode Penelitian Penddikan ( Pendekatan Kuantitatif, Kualitatif. Dan RED). Bandung : Afabeta.

Sulaiman, a. (2010). Implikasi Dalam Proses Pendidikan. JURNAL INKLUSI, 30-33. 
Syah, .. (2014). PSIKOLOGI PENDIDIKAN . BANDUNG : PT. Remaja Rosda Karya.

Wibowo, I. S. (2018). Hubungan Peran Guru Dalam Proses Pembelajaran Terhadap Prestasi Belajar Siswa . Jurnal Gentala Pendidikan Dasar , 30-33.

Yerusalem, M. R. (2015). Desain dan Implementasi Sistem pembelajaran jarak jauh Di Program Studi Sistem Komputer. Jurnal Teknologi dan Sistem Komputer, 9-10. 